\title{
An Imported Case of Falciparum Malaria Infection in Japanese Elderly Primigravida
}

\author{
Nobuyuki Mishima ${ }^{1,2) *}$, Seiji Kanda ${ }^{1)}$, Koichiro Tabuchi ${ }^{1,2)}$, Pheophet Lamaningao ${ }^{1)}$ \\ Hiroyuki Amano ${ }^{1)}$, Yorihiko Horikoshi ${ }^{3)}$ and Toshimasa Nishiyama ${ }^{1,2)}$ \\ ${ }^{1)}$ Department of Public Health, Kansai Medical University \\ ${ }^{2)}$ The Center of Travel Medicine, Kansai Medical University Takii Hospital \\ ${ }^{3}$ Department of Obstetrics and Gynecology, Kansai Medical University Takii Hospital
}

\section{高齢初妊婦における熱帯熱マラリアの輸入感染症例}

\author{
三島 伸介 ${ }^{1,2) *}$ ，神田 靖士 ${ }^{1)}$, 田淵幸一郎 ${ }^{1,2)}$, Pheophet Lamaningao ${ }^{1)}$ \\ 天野 博之 ${ }^{1)}$, 堀越 順彦 ${ }^{3)}$, 西山 利正 ${ }^{1,2}$ \\ 1)関西医科大学公衆衛生学講座 \\ 2)関西医科大学附属滝井病院海外渡航者医療センター \\ 3)関西医科大学附属滝井病院産婦人科
}

Received 30 March, 2011 / Accepted 1 October, 2011

\begin{abstract}
:
Malaria is endemic in tropical countries, but it is not in Japan. Approximately less than one hundred imported cases of malaria infection are reported annually in Japan, while no domestic case has been reported for more than 50 years. A few imported cases of malaria in pregnant women have been reported. However, in these cases it is difficult to select the appropriate drugs for pregnant women because of the limited availability of antimalarial drugs in Japan. Medical staffs in Japan are confronted with difficulties in selecting antimalarial drugs for the treatment of pregnant patients. Only three antimalarial drugs are approved under the Pharmaceutical Affairs Law of Japan and the law regulates that all of them are contraindicated for pregnant women. In the case discussed in this article, a 40-year-old primigravida is in her second trimester of gestation. She lived in Malawi and Gabon for several years, had been clinically diagnosed with malaria several times, and had taken antimalarial drugs. Therefore, it can be presumed that this patient could be semi-immune to malaria. Mefloquine was administered for treatment and the patient was cured. No serious side effects seemed to occur to the mother or the fetus during the treatment period. Finally, she delivered a baby boy by natural childbirth at 39 weeks of gestation, and his Apgar score was 9. Both of them were fine up to April 2010.

We experienced a case successfully treated with mefloquine hydrochloride against falciparum malaria of Japanese elderly primigravida.
\end{abstract}

Key words: Falciparum malaria, Pregnancy, Mefloquine, Drug resistance, Pharmaceutical affairs law of Japan

要旨:

マラリアは熱帯諸国を中心として流行が見られるが，現在の日本においてはその流行は見られない. 輸入感染 症として日本ではマラリアが年間数十例程度報告されているものの，日本での土着発生例は 50 年以上にわたっ て認めていない. また, 妊婦のマラリア輸入感染例も少数ながら報告されている. しかしながら, 高齢初妊婦の 症例報告はまだなされていない。日本においてマラリア治療を行う際に問題となるのは, 日本の薬事法で承認さ れているマラリア治療薬は 3 種類しかないということであり, 更にはその 3 種類の全てが妊婦への投与禁忌と なっていることである。こうした状況のため, 日本において妊婦のマラリア症例に対して適切な治療薬を選択す るのが極めて困難となる. 本症例は妊娠第 2 期における 40 才の高齢初妊婦の輸入熱帯熱マラリア症例である. 本 
患者は研究目的でマラウイとガボンに数年の滞在歴があり, 滞在中に何度となく臨床的にマラリアと診断され て, 治療を受けてきた。従って, 本患者はマラリア原虫に対してある程度の免疫を有していると考えられた. 治 療薬として塩酸メフロキンが投与され, 治療薬による重篤な副反応の出現もなく治癒するに至った. 退院後, 妊 娠週数第 39 週において自然分婏にて健常男児を出産した. アプガースコアは 9 点であった. 2010 年 4 月の時点 において，母子共に健康であることを確認した。

キーワード：熱帯熱マラリア，妊婦，メフロキン，薬剤抵抗性，薬事法

\section{Introduction}

Malaria is a common parasitic disease in tropical countries, but it could be preventable and treatable if the proper preventive methods and treatment are taken. Though, malaria still causes terrible health problems, especially to children and pregnant women. If plasmodium species infect a pregnant woman, it is detrimental to the mother and the fetus. Among the several species of Plasmodium, Plasmodium falciparum infection will bring the most serious health problems to the mother. The severity depends on the mothers' background premunition. Pregnant women residing in low endemic areas are at high risk of severe and cerebral malaria and death ${ }^{1)}$. Babies born of malaria-infected mothers have a lower birth weight and, therefore, are at the higher risk of congenital diseases and infant death. Approximately less than one hundred imported cases of malaria are reported annually in Japan and a case of stillbirth from mother with falciparum malaria has been reported ${ }^{2}$. Seven imported cases of malaria during pregnancy were reported in these several years ${ }^{2-6,14,15)}$. However, there are no case reports of Japanese elderly primigravida. It is estimated that more cases can potentially occur, including undiagnosed malaria. Recently more and more people in Japan and other countries travel abroad for various reasons, such as business, for studies, vacation, to visit friends and relatives, immigration, and so on. Therefore, the risk of malaria infection in Japan should be recognized.

Regarding the treatment for pregnant patients, artemisinin-based combination therapy (ACT) and clindamycin are recommended worldwide for uncomplicated falciparum malaria in the second and third trimester of gestation ${ }^{7,8)}$. The treatment for pregnant women must be selected very carefully. Only three types of antimalarial drugs are approved under the Pharmaceutical Affairs Law of Japan. These drugs are quinine hydrochloride, sulfadoxine-pyrimethamine, and mefloquine hydrochloride. All of them are orally administered drugs. However, these are contraindicated for pregnant patients under that law. Some orphan antimalarial drugs are provided to designated hospitals and medical institutions, but the number of these institutions is very limited. So, we face difficulties selecting antimalarial drugs to treat serious and special cases, such as pregnant patients. We encountered an imported case of falciparum malaria during pregnancy, and in this article we will report the clinical progress of this case and analyze the use of antimalarial drugs available in Japan.

\section{Case Presentation}

A 40-year-old Japanese primigravida (22 weeks of gestation), a researcher at a university in Japan, returned from Gabon. She visited the travel clinic with a fever (temperature $38.5^{\circ} \mathrm{C}$ ), headache, joint pain, and was admitted to Kansai Medical University Takii hospital because the dipstick rapid diagnostic test for Plasmodium falciparum was positive. She was simultaneously presented at the 22 weeks of gestation. Regarding the rest of her medical history, she had had an appendectomy because of acute appendicitis when she was 29 years old. She had been clinically diagnosed with malaria every year since travelling to Malawi and treated with quinine. She has no family history of hemoglobinopathy, and no specific allergies to foods, drugs, or other substances. There was no history of sexually transmitted diseases. She does not smoke cigarettes, and drinks occasionally. She held a history of vaccination, including the pretravel vaccinations as follows: inactivated hepatitis A vaccine (3 times), inactivated hepatitis $B$ vaccine ( 3 times), tetanus toxoid vaccine (3 times), inactivated rabies vaccine ( 3 times), and live-attenuated yellow fever vaccine before travelling to Gabon.

She had stayed in Malawi from 1998 to 2001 to conduct a field study. After completing her research in Malawi, she undertook field study that involved camping in Gabon starting in 2003, where she stayed there for six to nine months. She did not take malaria chemoprophylaxis. She had been clinically diagnosed with malaria at least once every year from the start of staying in the endemic areas of Gabon with the treatment of artemether-lumefantrine. She had taken 
An Imported Case of Falciparum Malaria Infection in Japanese Elderly Primigravida

Table 1. Transition of laboratory data during hospitalization

\begin{tabular}{|c|c|c|c|c|c|c|}
\hline Test item & $\begin{array}{c}\text { On arrival } \\
\text { at clinic ward }\end{array}$ & $\begin{array}{l}20 \text { hours } \\
\text { after arrival }\end{array}$ & $\begin{array}{l}40 \text { hours } \\
\text { after arrival }\end{array}$ & $\begin{array}{l}64 \text { hours } \\
\text { after arrival }\end{array}$ & $\begin{array}{l}76 \text { hours } \\
\text { after arrival }\end{array}$ & $\begin{array}{l}\text { Discharge ( } 8 \text { days } \\
\text { after presentation) }\end{array}$ \\
\hline Hematocrit & 36.5 & 31.4 & 33.4 & 31.4 & 31.6 & 31.6 \\
\hline Hemoglobin & 12.3 & 10.7 & 11.5 & 10.7 & 10.9 & 10.7 \\
\hline White-cell count & 5,000 & 4,300 & 5,500 & 7,300 & 6,700 & 7,400 \\
\hline \multicolumn{7}{|l|}{ Differential count } \\
\hline Neutrophils & 75.2 & 93.0 & 78.0 & 87.7 & 76.6 & 62.5 \\
\hline Basophils & 0.4 & 0.0 & 0.0 & 0.1 & 0.3 & 0.1 \\
\hline Eosinophils & 1.4 & 0.0 & 0.0 & 0.3 & 0.5 & 2.0 \\
\hline Lymphocytes & 13.5 & 5.0 & 15.5 & 7.0 & 13.4 & 27.3 \\
\hline Monocytes & 8.1 & 1.5 & 6.0 & 4.5 & 8.9 & 5.9 \\
\hline Platelet count & 18.9 & 14.2 & 9.2 & 8.7 & 8.2 & 17.8 \\
\hline Blood parasites & $\begin{array}{c}0.07 \% \\
\text { of red cells }\end{array}$ & $\begin{array}{c}0.08 \% \\
\text { of red cells }\end{array}$ & $\begin{array}{c}0.5 \% \\
\text { of red cells }\end{array}$ & $\begin{array}{c}<0.01 \% \\
\text { of red cells }\end{array}$ & negative & negative \\
\hline Creatinine & 0.52 & 0.61 & 0.48 & 0.58 & 0.56 & 0.58 \\
\hline Sodium & 137 & 137 & 138 & 137 & 136 & 141 \\
\hline Potassium & 3.9 & 3.8 & 3.3 & 3.4 & 3.2 & 3.6 \\
\hline Chloride & 102 & 102 & 104 & 105 & 104 & 106 \\
\hline LDH & 162 & 144 & 158 & 155 & 160 & 151 \\
\hline CRP & 3.35 & 2.35 & 7.06 & 5.05 & 5.23 & 0.95 \\
\hline
\end{tabular}

sulfadoxine-pyrimethamine once for treatment of malaria during her stay in Gabon (from 2003 to 2008), but it was ineffective and the treatment was changed to artemetherlumefantrine. She became pregnant in September 2008. She had received prenatal care at Gabon's local hospital since 12 weeks of gestation. She and her fetus had been well with no health problems under the medical care received at the local hospital.

The patient returned to Japan on the $22^{\text {nd }}$ December 2008. On the day following return, she had a fever $\left(38.5^{\circ} \mathrm{C}\right)$, headache, and joint pain. Her fever dropped to her usual level on the $24^{\text {th }}$ but she worried about the pregnancy and the unfavorable effects to her fetus from the malaria infection, and therefore, she visited the hospital.

Upon physical examination, the patient's consciousness was clear and her blood pressure was $110 / 64 \mathrm{~mm} \mathrm{Hg}$, with a pulse of 80 beats per minute, and respiration was 18 breaths per minute. The oxygen saturation was $99 \%$ in the ambient air. Her temperature was $36.5^{\circ} \mathrm{C}$, height $153 \mathrm{~cm}$, and weight $46 \mathrm{~kg}$. The skin was warm to the touch, with brisk capillary refill; there were no cutaneous eruptions, petechiae, or visible insect bites. The sclerae were nonicteric. Cardiac examination revealed a regular rate and normal sinus rhythm and no murmurs. There was no lymphadenopathy or hepatosplenomegaly. Neurologic examination revealed no abnormalities. Urinalysis showed normal range. We did not perform chest radiograph. During the obstetrics inspection, the ultra- sonographic examination of the pelvis showed a single intrauterine gestational sac containing a normal-appearing fetus with a normal heart rate. The results of the laboratory tests in the hospital were shown in Table 1. The analysis of the Giemsa-stained peripheral-blood thin smear ( $\mathrm{pH}$ 7.2) showed infected erythrocytes with the presence of $P$. falciparum (Figure 1). Appearance of erythrocytes looked normal and erythrocytes did not enlarge. Mature trophozoites and schizonts were not detected, however, early trophozoites were detected in the erythrocytes and some erythrocytes contained plural early trophozoites. The infection rate of the parasite was around $0.07 \%$. PCR was performed with the peripheral blood for differential diagnosis of Plasmodium species. We used the DNA extracted from the peripheral blood as a template and performed PCR with the specific primer for $P$. falciparum, dihydrofolate reductase-thymidylate synthase gene (GenBank accession number: J03028) ${ }^{9}$. The specific primers of this gene were designed to amplify the region from $675 \mathrm{bp}$ to $1,083 \mathrm{bp}$ as follows: forward (5'-TGT TAG CGA TGT ATA TAC TAG TAA C-3') and reverse (5'TTC GAT CAC TTT GTT TAT TTC CAT T- $\left.3^{\prime}\right)^{10)}$. The lane 1 and 2 demonstrate negative and positive control, respectively. The blood sample of this patient could be detected specific band ( $409 \mathrm{bp}$ ) derived from the specific primer of $P$. falciparum. This result demonstrated that this patient was infected with $P$. falciparum (Figure 2).

Twenty hours after admission, the patient's temperature 

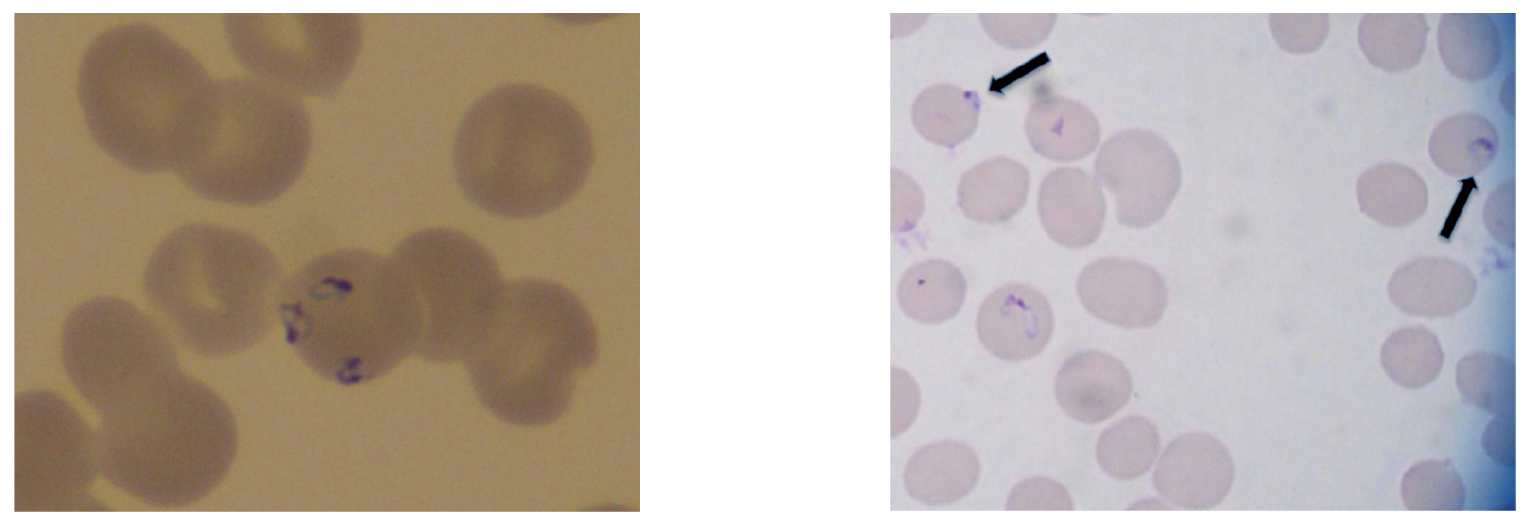

Fig. 1. Giemsa-stained peripheral-blood thin smear (pH 7.2)

A: three early trophozoites with double-chromatin-dotted in the erythrocyte (magnification: $\times 1,000$ )

B: two early trophozoites and trophozoite in the margin of erythrocyte (arrows, magnification: $\times 400$ )

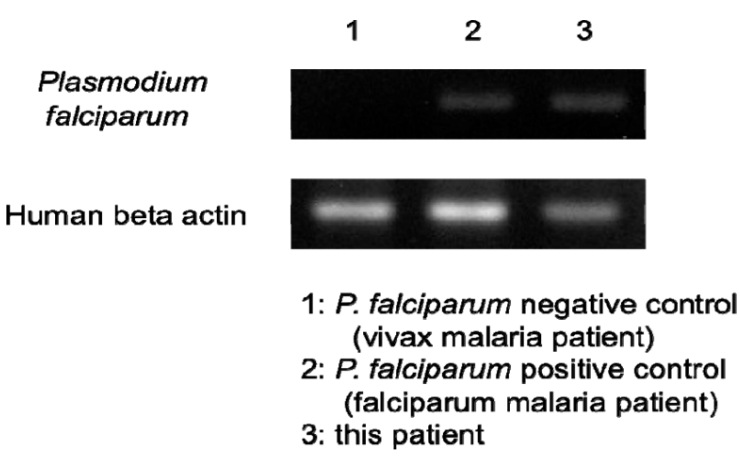

Fig. 2. Detection of Plasmodium gene from Peripheral Blood by PCR

DNA from the peripheral blood was used as a template and PCR was performed with the primer of a domain conserved in Plasmodium falciparum. The lane 1 (extracted DNA derived from patient infected with $P$. vivax) and 2 (extracted DNA derived from patient infected with $P$. falciparum) demonstrate negative and positive control, respectively. The lane 3 (extracted DNA derived from this patient) demonstrated the positive band from the specific primer of P. falciparum.

rose up to $39.3^{\circ} \mathrm{C}$ and her conjunctivas were congested. However, her consciousness was still clear and her general status was stable. Her blood pressure was 102/62 mm Hg, with a pulse of 101 beats per minute. Respiratory rate was 22 per minute, the oxygen saturation was $99 \%$ in the ambient air. Examination of Giemsa-stained peripheral-blood thin smear showed that $0.08 \%$ of the patient's erythrocytes was infected with P. falciparum.

Firstly, we informed the patient that the administration of mefloquine hydrochloride was contraindicated to pregnant women under the Pharmaceutical Affairs Law of Japan, and then we explained both the effectiveness and the risk of mefloquine to the mother and the fetus at the 22 weeks of gestation. We could obtain a written informed consent for mefloquine administration. At thirty hours after admission, oral mefloquine hydrochloride $275 \mathrm{mg} \times 2$ tablets were administered two times with the six-hour intervals. No obvious side effects of the drug appeared and both the mother and the fetus were stable status after mefloquine administration. Forty hours after mefloquine administration, her temperature was temporarily up to $38.1^{\circ} \mathrm{C}$, but her general status was stable. Parasites also disappeared two days later after mefloquine administration completion. Eight days after admission to the hospital, the patient was in remission and was discharged. This patient delivered a baby boy by natural childbirth at 39 weeks of gestation and his Apgar score was 9 . Both of mother and child were fine up to April 2010.

\section{Discussion}

When faced with the selection of antimalarial drugs for the treatment of pregnant patient, many points should be taken into consideration, such as in which trimester of pregnancy, when and where was she infected, presence or absence of complications, etc. This case showed four risks: the elderly primigravida, the second trimester of gestation, falciparum malaria transmitted in Gabon, and the limited availability of anti-malarial drugs for pregnant patients in Japan. At present, only three kinds of antimalarial drugs are available for use in Japan, those are quinine hydrochloride, sulfadoxine-pyrimethamine and mefloquine hydrochloride. However, the prescription of these drugs is contraindicated for pregnant patients under the Pharmaceutical Affairs Law of Japan. Although there are some proposals evaluating the risk in using some of these drugs on pregnant patients ${ }^{11,12)}$, 
little authorized information is available about administering antimalarial drugs during pregnancy.

Therefore we checked the recommendations of Food and Drug Administration of the United States (FDA). Sulfadoxinepyrimethamine and mefloquine hydrochloride are classified as C. Quinine hydrochloride is classified as X. FDA defines use-in-pregnancy ratings as follows: Category $\mathrm{C}$-Animal studies show toxicity, human data are insufficient, but clinical benefit may exceed risk; Category $\mathrm{X}$ - There is evidence of fetal abnormalities in humans, and risk exceeds benefit. The infection caused by $P$. falciparum in the Gabon is estimated to have resistance against chloroquine and sulfadoxinepyrimethamine ${ }^{13)}$. Two cases of falciparum malaria in Japan where pregnant patients were treated by administering mefloquine hydrochloride were reported as successful therapy ${ }^{14,15)}$. Some papers described the safety of mefloquine in pregnancy. Nosten $\mathrm{F}$ et al. reported that mefloquine was not associated with abortion, low birth weight, neurological retardation, or congenital malformations ${ }^{16}$. Penelope A et al. reported that the risk of mefloquine was considerably lower than the other antimalarials even in the first trimester of gestation $^{17}$. Therefore we selected mefloquine hydrochloride to treat falciparum malaria in this pregnant woman.

Research Group on Chemotherapy of tropical diseases is organized in Japan and the related medical institutions provide some orphan drugs for tropical diseases treatment ${ }^{18)}$. Every Japanese medical institution is not equipped with these kinds of drugs including antimalarial drugs. Therefore, it is still difficult to select proper antimalarial drugs, especially for the treatment of pregnant women in Japan because of limited therapeutic drug. Hence it is very important to cautiously discuss the indication of anti-malarial drugs for pregnant patients in Japan.

The severity of falciparum malaria is a grave concern for the mothers' background premunition. In the case presented here, the patient was born and raised in Japan, a nonendemic area of malaria. Moreover, she was an elderly primigravida. The late childbearing increases the risk of abortion and stillbirth. It can be also the risk for mother's health, especially for primigravida. The cellular immunity is depressed during pregnancy ${ }^{19)}$. Therefore, she could have been at high risk for severe and cerebral malaria and death. Taking a look at her travel history, she had stayed in the Malawi for four years from 1998 to 2001, and in Gabon for six years from 2003 to 2008 . She had been clinically diagnosed with malaria every year since going abroad, except 2008, and had taken antimalarial drugs each time. It was estimated that she had suffered from malaria many times; more than 4 times in Malawi and more than 5 times in Gabon. Therefore, it could be presumed that she was in a semi-immune status for malaria and could recover from malaria without any serious complications.

In summary, a Japanese pregnant woman was infected with falciparum malaria in the second trimester of gestation, and she recovered with the administration of mefloquine without recrudescence. Despite the risk of the elderly primigravida, she delivered a healthy baby boy at term. Although the administration of mefloquine hydrochloride is contraindicated for pregnant patients under Japanese Law, mefloquine hydrochloride treatment appeared safe and effective for uncomplicated malaria in the second trimester of gestation of the elderly primigravida.

\section{Acknowledgments}

We are deeply grateful to Dr. Katsuhiko Yasuda, Department of Obstetrics and Gynecology, Kansai Medical University Takii Hospital, for examining gynecological checkup for this patient. It was great help for treatment of falciparum malaria in pregnancy.

\section{Addendum}

Food and Drug Administration of United States updated the categorization of mefloquine from a pregnancy category $\mathrm{C}$ drug to category $\mathrm{B}$, based on their review of the published data on mefloquine use during pregnancy. The Center for Disease Control and Prevention released the recommendation of the antimalarial drug mefloquine for pregnant women both as a malaria treatment option and as an option to prevent malaria infection for all trimesters on October $25^{\text {th }} 2011$.

\section{References}

1. Shulman CE, Dorman EK, Bulmer JN. Malaria as a cause of severe anaemia in pregnancy. Lancet 360: 494, 2002.

2. Gomi H, Matsuoka H. A case report of a Japanese pregnant woman infected falciparum malaria returning from Guinea. Kansenshogaku Zasshi 81: 777-778, 2007.

3. Kawaguchi R, Endo H, Sugiura K, Ooura K, Akiyama Y, Isonishi S, Tanaka T, Kumagai M, Watanabe N, Ohtomo H. A case of falciparum malaria in pregnancy. Tokyo $\mathrm{J}$ Obstet Gynecol 51: 26-29, 2002.

4. Takashita N, Abe T, Suzuki H, Suzuki K, Takahashi F, Kobayashi K, Akaike J, Ikeda Y, Kanemoto H, Okuda H, Matsuya M, Sakai H, Kimura H, Yonezawa K, Tosaka M. A 
case of vivax malaria after a miscarriage. J Kushiro City General Hospital 12: 125-128, 2000.

5. Suga H, Doi M, Hayashi R, Tatsumi H. A case of malaria infection in pregnancy. J Kanagawa Med Association 24: 240, 1997.

6. Murayama K. A case of vivax malaria at the eighth month of pregnancy. J Saitama Med Association 454: 34-38, 1988.

7. Nosten F, McGready R, Mutabingwa T. Case management of malaria in pregnancy. Lancet 7: 118-125, 2007.

8. Department of Health and Human Services Centers for Disease Control and Prevention. Safer, healthier, people, treatment of malaria (Guidelines for Clinicians), 2007 March.

9. Bzik DJ, Li WB, Horii T, Inselburg J. Molecular cloning and sequence analysis of the Plasmodium falciparum dihydrofolate reductase-thymidylate synthase gene. Proc Natl Acad Sci USA 84: 8360-8364, 1987.

10. Snounou G, Viriyakosol S, Zhu XP, Jarra W, Pinheiro L, do Rosario VE, Thaithong S, Brown KN. High sensitivity of detection of human malaria parasites by the use of nested polymerase chain reaction. Mol Biochem Parasitol 61: 315320, 1993.

11. National Center for Child Health and Development, Pregnancy and Medicine Information Center (http://www.ncchd.go.jp/ kusuri/index.html).
12. Japan Society of Obstetrics and Gynecology. Treatment Guideline of Obstetrics and Gynecology, 2008: 31-33.

13. International travel and health situation as on 1 January 2010 , World Health Organization.

14. Okamura N, Itsumi H, Suzuki S, Kakizaki K. Falciparum malaria in pregnancy. J Kushiro City General Hospital 15: 135-141, 2003.

15. Kano S, Suzuki C, Masuda G, Suzuki M. A recrudescence of falciparum malaria in a pregnant Japanese woman successfully treated with mefloquine. Clin Parasitol 7: 67-69, 1996.

16. Nosten F, Vincenti M, Simpson J, Yei P, Thwai KL, de Vries A, Chongsuphajaisiddhi T, White NJ. The effects of mefloquine treatment in pregnancy. Clin Infect Dis 28: 808-815, 1999.

17. Penelope A, et al. Safety of mefloquine and other antimalarial agents in the first trimester of pregnancy. J Travel Med 5: 121-126, 1998.

18. Research Group on Chemotherapy of Tropical Diseases, Japan (http://www.miyazaki-med.ac.jp/parasitology/orphan/ HTML/page5.html).

19. Sholapurkar SL, Mahajan RC, Gupta AN, Wangoo A. Cellular immunity in pregnant and non-pregnant women with malarial infection. Asia-Oceania J Obstet Gynecol 16: 27-32, 1990. 